\title{
Research on Structural Behavior of Concrete Encased Steel Castellated Beam for Different Sections
}

\author{
V.Senthil kumar, P.Nandhakumar, M.Indrajit, P. Swathika
}

\begin{abstract}
This paper study about the analytical behaviour of Concrete beam encased with Steel castellated beam as composite member with various web opening section of the castellated beam as optimization of section by its maximum Load carrying capacity and deflection. The modelling and Finite Element Analysis was done using Ansys Workbench 16.2. The Concrete beam having section size of $150 \mathrm{~mm} \times 170 \mathrm{~mm} x$ $1500 \mathrm{~mm}$ encased with Structural Steel ISMB100 of span $1400 \mathrm{~mm}$ is used for castellated beam for various shape of web opening are provided. The parametric study has shown the Deflection and Load carrying capacity of the various cross sectional beams with Hexagonal opening (inscribed in the circle $25 \mathrm{~mm}$ radius) which has high load carrying capacity and the less deflection while compared to the other sections of circular web opening (25mm radius), hexagonal wide web opening $(25 \mathrm{~mm}$ with 1:1:1 web ratio), and rectangular web opening of $(25 \mathrm{~mm} x$ $50 \mathrm{~mm}$ ). Alternate incremental loading is applied by using Ansys workbench 16.2 and results and graphs are plotted.

Keywords: Composite Beam, Castellated Beam, finite element analysis, web opening, circular web opening, hexagonal web opening, rectangular web opening, hexagonal wide web opening.
\end{abstract}

\section{INTRODUCTION}

In construction industry composite structures are widely used. In general concrete is high in compression strength and steel is high in tension strength. In composite construction the steel and concrete combined in such a fashion that the advantages of the both the materials are used effectively. In the composite member like steel encased i-section in increases the fire resistance and also it will increase the load carrying capacity of the section.

A castellated beam is a beam where I section is subjected to a longitudinally cut along its web followed in a specific pattern in order to divide it, and design the beam with a higher depth of web will be advantage while cutting. Castellated beam has a regular pattern of holes (circular, hexagonal or octagonal) in its web and made from hot rolled section, which is first divided by a lengthwise cut into two halves following a special pattern, then welded together to increase its depth. Sometimes additional flats are used between two web cuts for even further deeper section. Special pattern can even generate tapered beam, where

Revised Manuscript Received on August 14, 2019.

V.Senthil kumar, Assistant Professor (SRG), Department of Civil Engineering, Kumaraguru College of Technology, Coimbatore641049.T.N, India (Email id: senthilkumar.v.ce@kct.ac.in)

P.Nandhakumar, - Assistant Professor, Department of Civil Engineering, Kumaraguru College of Technology Coimbatore-641049. T.N, India (Email id: nandhakumar.p.ce@kct.ac.in)

M.Indrajit, PG student, Department of Civil Engineering, Kumaraguru College of Technology, Coimbatore-641049. T.N, India

P. Swathika PG Student, Department of Civil, Bannari Amman Institute of Technology, Sathymangalam, Erode, Tamilnadu, India. depth of the beam will gradually increase along the length of the beam.

\section{MATERIAL PROPERTIES IN ANSYS}

\section{A. Material Properties}

Table 1. Properties of Concrete

\begin{tabular}{|c|c|}
\hline Modulus of Elasticity & $22360 \mathrm{~N} / \mathrm{mm}^{2}$ \\
\hline Poisson Ratio & 0.15 \\
\hline $\begin{array}{c}\text { Compressive Yield } \\
\text { Strength }\end{array}$ & $20 \mathrm{~N} / \mathrm{mm}^{2}$ \\
\hline
\end{tabular}

Table 2. Properties of Hot Rolled Steel

\begin{tabular}{|c|c|}
\hline Modulus of Elasticity & $2 \times 10^{5} \mathrm{~N} / \mathrm{mm}^{2}$ \\
\hline Poisson Ratio & 0.3 \\
\hline Yield Strength & $310 \mathrm{~N} / \mathrm{mm}^{2}$ \\
\hline
\end{tabular}

\section{B. Modelling and Meshing}

The modelling is done using AutoCAD 2016 as a 2D element. The thickness is assumed very smoothly over the area of the element. It was then imported in the DESIGN MODELLER of ANSYS 16.2 for the verification of the solid element. Then the ANSYS STATIC STRUCTURAL was opened to mesh the element. It was found that the good stimulation results could be obtained by using the element (mesh) in medium size respectively.

\section{Specimen Detail}

Table 3. Specimen Detail

\begin{tabular}{|c|c|}
\hline Beam & $150 \times 170 \mathrm{~mm}$ \\
\hline $\begin{array}{c}\text { I Section - Hexagonal } \\
\text { opening }\end{array}$ & $\begin{array}{c}25 \mathrm{~mm} \text { inscribed in } \\
\text { circle }\end{array}$ \\
\hline $\begin{array}{c}\text { I Section-Hexagonal } \\
\text { wide opening }\end{array}$ & $25 \mathrm{~mm}$ wide $(1: 1: 1)$ \\
\hline $\begin{array}{c}\text { I Section-Circular } \\
\text { opening }\end{array}$ & $25 \mathrm{~mm}$ Radius \\
\hline $\begin{array}{c}\text { I Section-Rectangular } \\
\text { opening }\end{array}$ & $25 \mathrm{~mm} \times 50 \mathrm{~mm}$ \\
\hline
\end{tabular}

Published By: 


\section{RESEARCH ON STRUCTURAL BEHAVIOR OF CONCRETE ENCASED STEEL CASTELLATED BEAM FOR DIFFERENT SECTIONS}

\section{Boundary Condition And Loading}

Concrete Beam of $150 \mathrm{mmx} 170 \mathrm{~mm} \times 1500 \mathrm{~mm}$ encased with castellated beam of hexagonal opening $25 \mathrm{~mm}$, hexagonal wide open of $25 \mathrm{~mm}$, circular opening $25 \mathrm{~mm}$ radius, rectangular opening of $25 \mathrm{~mm} \times 50 \mathrm{~mm}$ were modelled for a length of $1500 \mathrm{~mm}$ and the boundary conditions were modelled and analysed for the load carrying capacity. The end of the specimens were simply supported. The specimen were loaded at its mid-span till failure and the results were obtained by linear analysis. Step loaded form $20 \mathrm{kN}$ to $600 \mathrm{kN}$.

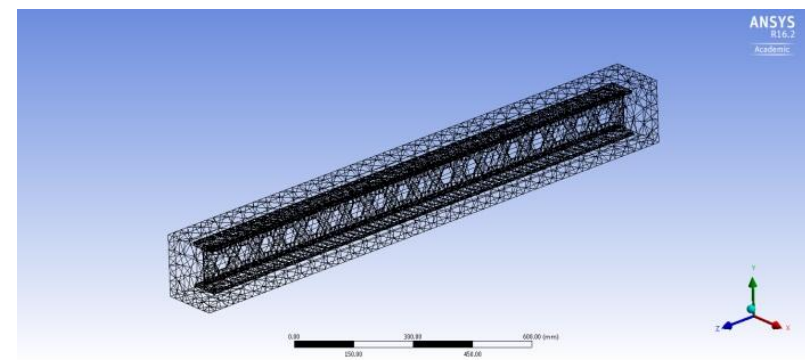

Fig 1. Mesh of hexagonal opening

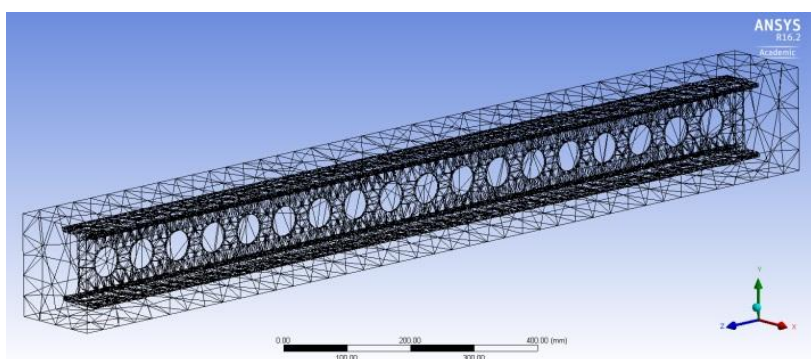

Fig 2. Mesh of rectangular opening

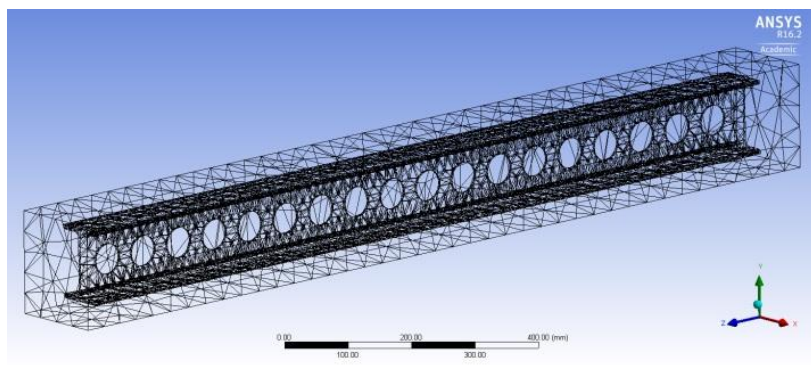

Fig 3. Mesh of circular opening

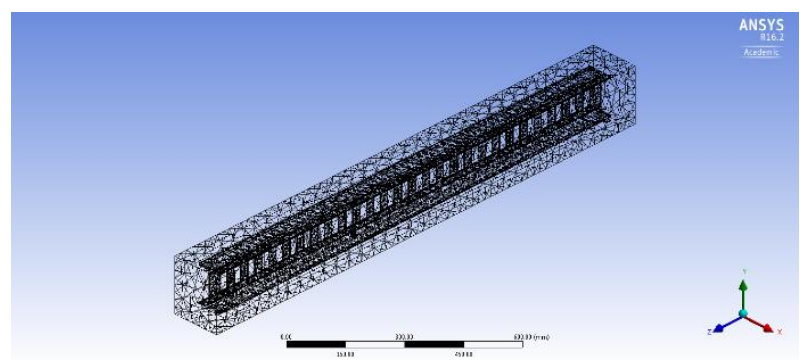

Fig 4.Mesh of hexagonal wide opening

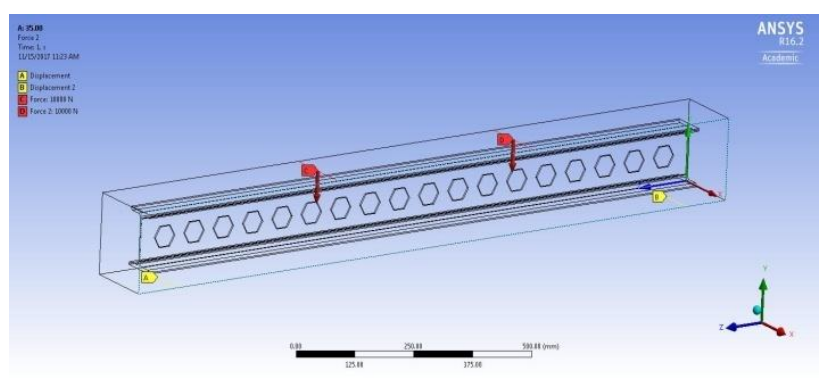

Fig 5. Loading and support conditions

\section{NUMERICAL INVESTIGATION}

The concrete encased steel castellated beams of various openings are numerically analysed in transverse two point loading at the mid span with simply supported condition.

Loading was given till the failure. The vertical deformation, maximum principal stress maximum principal strain by calculating using ANSYS 16.2 linear analysis is done and the obtained results were given below.

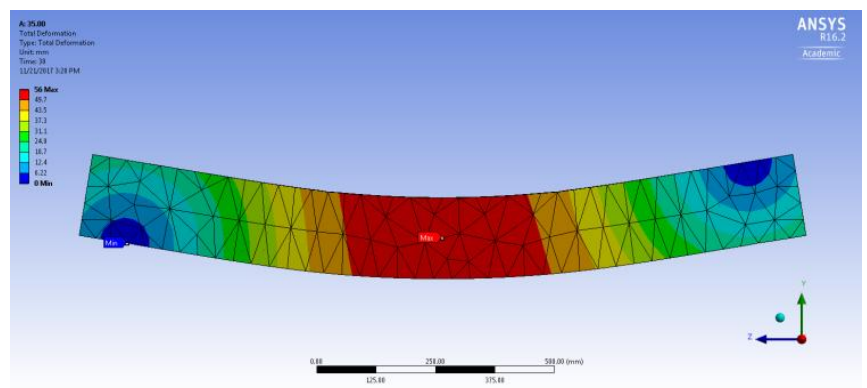

Fig 6.Total deformation for hexagonal web opening

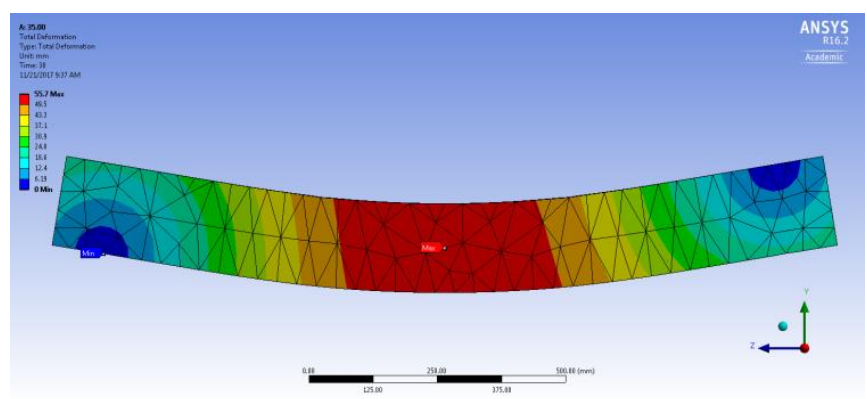

Fig 7.Total deformation for wide hexagonal web opening

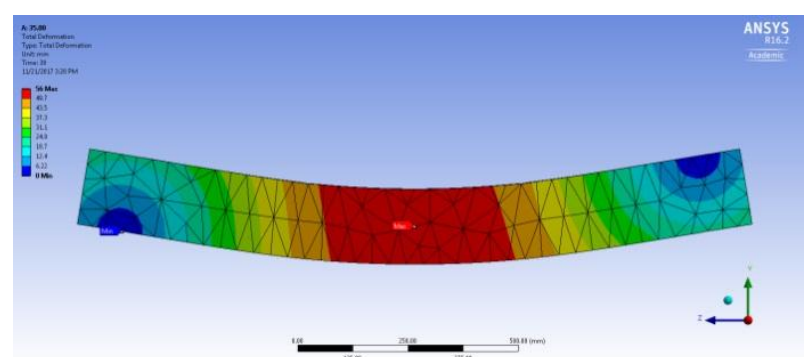

Fig 8.Total Deformation for circular web opening

\section{Published By:}

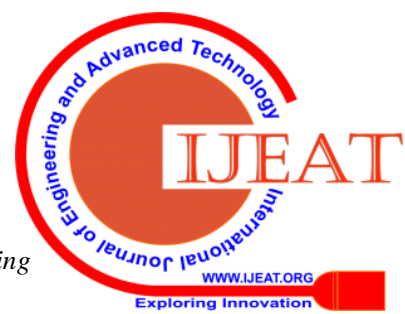




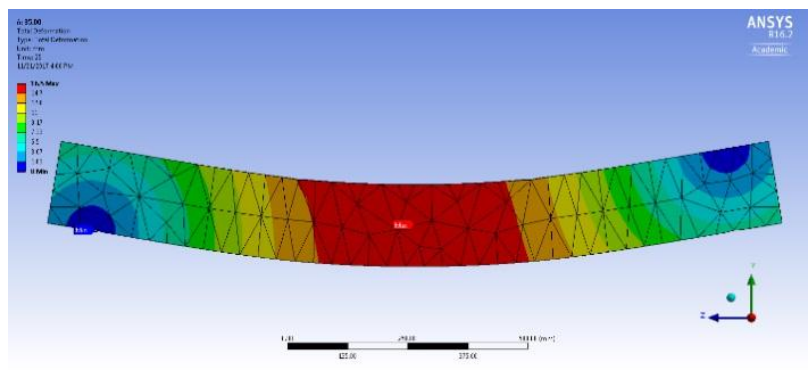

Fig 9.Total Deformation for rectangular opening

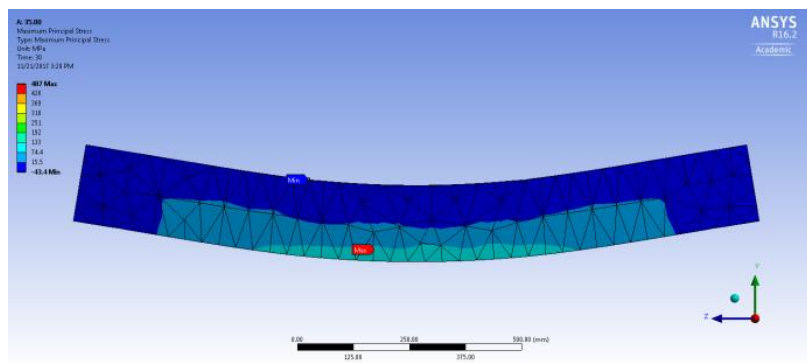

Fig 10.Maximum principal stress for Hexagonal web opening

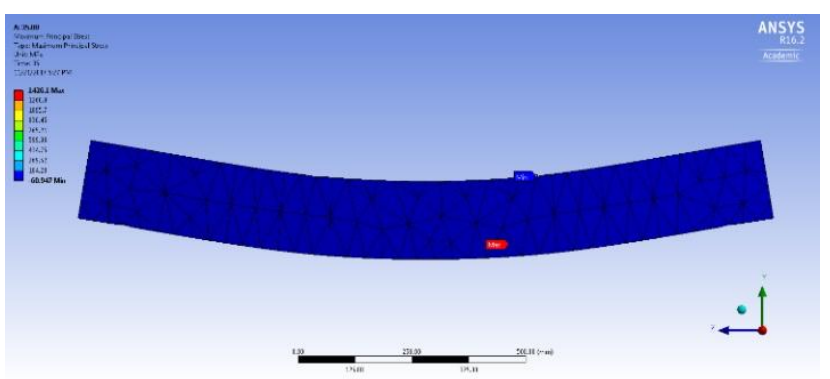

Fig 11.Maximum Principal Stress for circular web opening

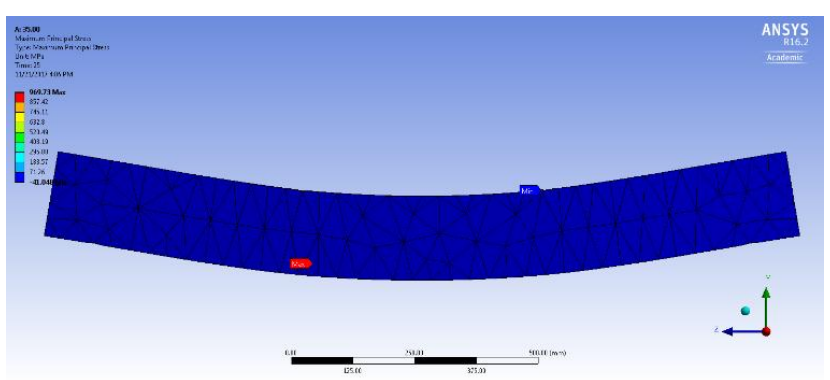

Fig 12. Maximum Principal Stress forRectangular web opening

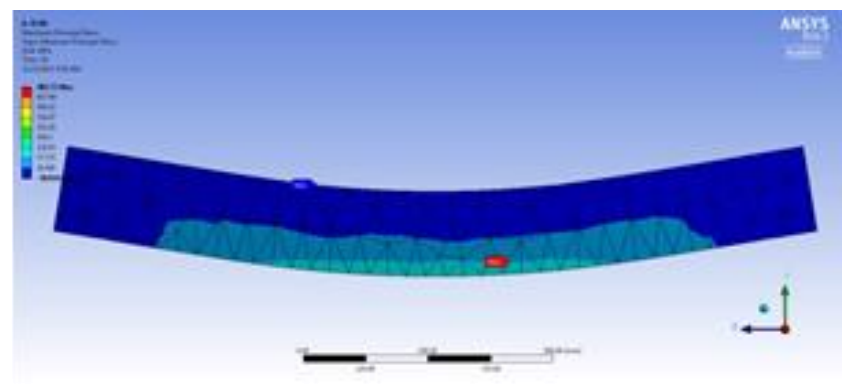

Fig 13. Maximum Principal Stress for wide hexagonal web opening

IV. RESULT AND DISCUSSION

DISCUSSION ON STRESS AND STRAIN INTENSITY
Table discussion of results:

\begin{tabular}{|c|c|c|c|c|}
\hline DESCRIPTION & $\begin{array}{c}\text { ULTIMATE } \\
\text { LOAD }(\mathbf{k N})\end{array}$ & $\begin{array}{c}\text { DEFORMATION } \\
(\mathbf{m m})\end{array}$ & $\begin{array}{c}\text { STRESS } \\
\left(\mathbf{N} / \mathbf{m m}^{2}\right)\end{array}$ & STRAIN \\
\hline $\begin{array}{c}\text { HEXAGONAL OPEN } \\
\mathbf{2 5} \mathbf{~ m m}\end{array}$ & 545 & 45.620 & 460.01 & 0.004455 \\
\hline $\begin{array}{c}\text { RECTANGULAR OPEN OF } \\
\mathbf{2 5 m m}\end{array}$ & 260 & 7.5954 & 460.50 & 0.002318 \\
\hline $\begin{array}{c}\text { CIRCULAR OPEN OF } \\
\mathbf{2 5} \mathbf{~ m m}\end{array}$ & 545 & 47.867 & 460.68 & 0.004444 \\
\hline $\begin{array}{c}\text { HEXAG0NAL WIDE } \\
\text { OPEN25 mm }\end{array}$ & 280 & 7.6801 & 460.50 & $2.31 \mathrm{E}-03$ \\
\hline
\end{tabular}

\section{STRESS- STRAIN}

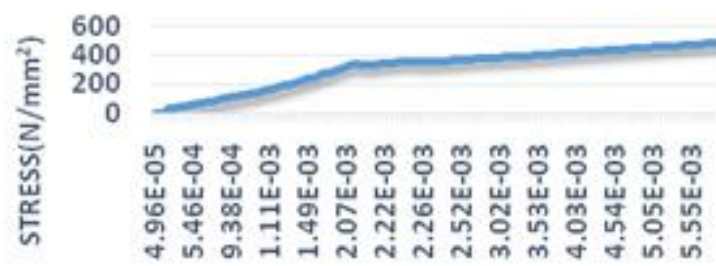

STRAIN

- STRESS STRAIN

Fig 14. Stress strain curve of hexagonal opening $25 \mathrm{~mm}$

\section{STRESS-STRAIN}

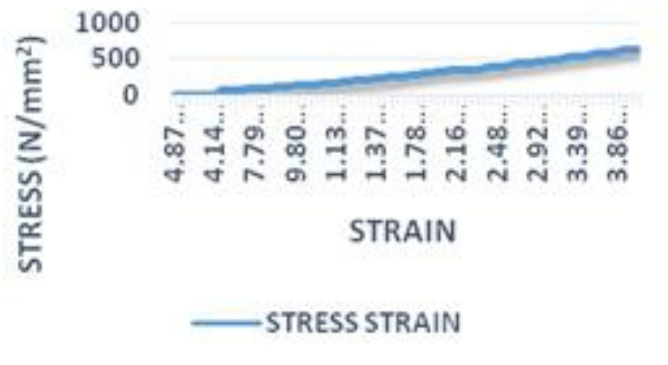

Fig 15. Stress strain curve of hexagonal wide opening

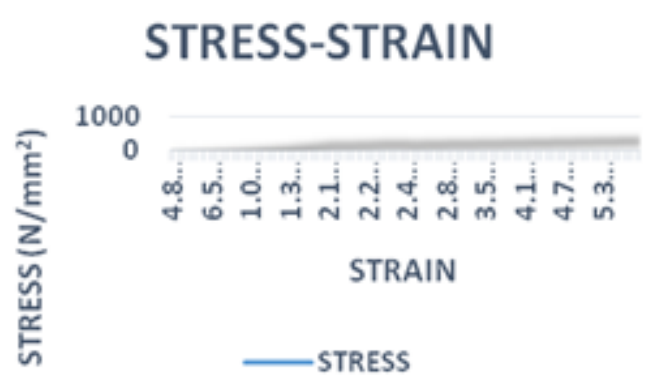

Fig 16.Stress strain curve of hexagonal opening $25 \mathrm{~mm}$

Published By:

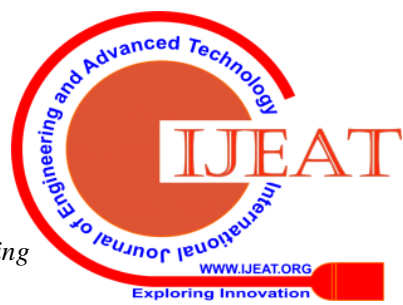




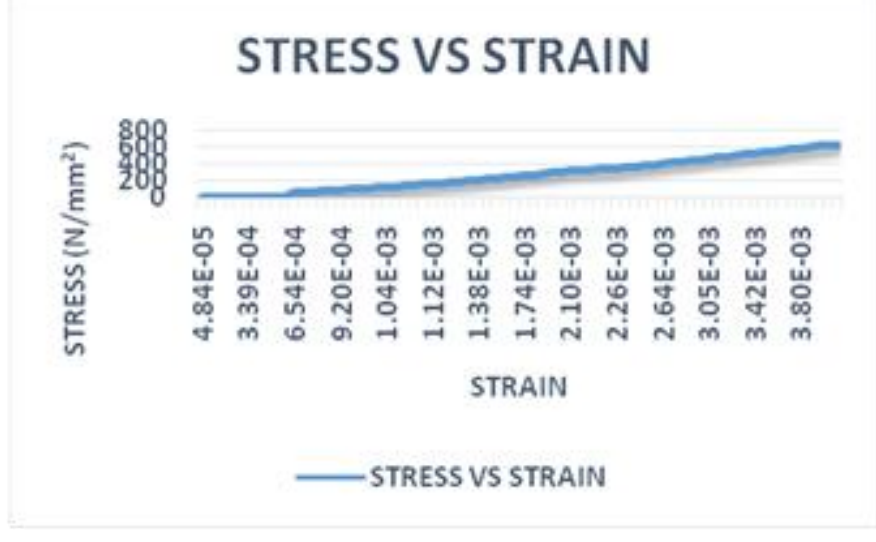

Fig17. Stress strain curve of rectangular opening $25 \mathrm{~mm}$

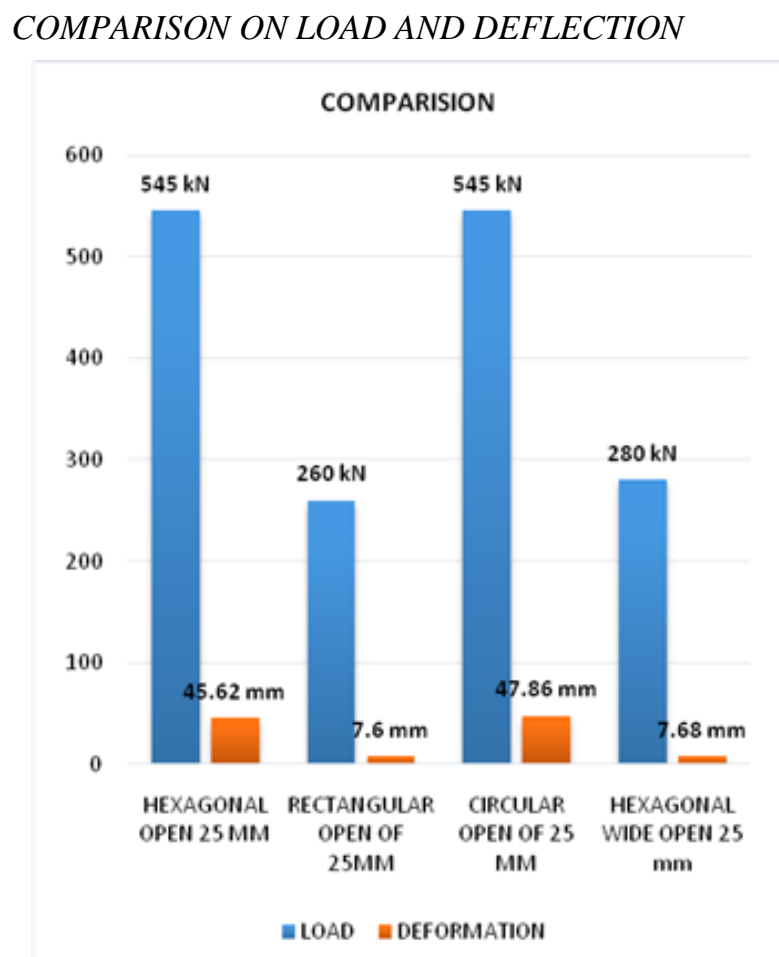

Fig 18. Comparison on Load and Deformation

\section{CONCLUSION}

From the results the following conclusions are made,

- Deflection is less in hexagonal opening of 25 mm while compared to the other sections.

- During Castellation process, the wastage is reduced compared to the circular sections which has an equivalent load carrying capacity.

- Load carrying capacity is higher when compared to usage of other sections like rectangular and hexagonal wide open, but equivalent load carrying capacity of circular sections.

- Using of castellated beam as composite the size of the depth of the beam can be reduced and it can used for long span and economical.

- It is concluded that, by selecting the hexagonal opening of $25 \mathrm{~mm}$ is more effective as mentioned above.

\section{REFERENCE}

1. SP: 6(1) - 1964 HANDBOOK FOR STRUCTURAL ENGINEERS, PART-1 STRUCTURAL STEEL SECTIONS

2. U ELAKEYA, A BHUVANESH SRE AND $P$ GAJALAKSHMI "Study on the Structural Behavior of Concrete Encased Steel Composite Members" ISSN 0974-5904, Volume 09, No. 03 June 2016, P.P.323-329.

3. Toprac AA, Cooke BR. An experimental investigation of open-web beams. Welding research council bulletin, vol 47. 1959. p. $1-10$.

4. Nethercot DA, Kerdal D. Lateral-torsional buckling of castellated beams. The Structural Engineering 1892; 60B (3): 53-61.

5. Xian Li, HenglinLv, Shuchun Zhou - "Flexural behavior of GFRP - reinforced encased steel composite beams", Journal of Construction and Building Material, volume no 28, p.p no. $255-262,2012$.

6. Dali Yao, Jinqing Jia, Feng Wub, Fang Yu,"Shear performance of prestressed ultra-high strength concrete encased steel beams ",Construction and Building Materials 52 (2014) 194-201

7. Sethuramalingam, T. K., and B. Nagaraj. "A comparative approach on PID controller tuning using soft computing techniques." International Journal of Innovations in Scientific and Engineering Research (IJISER) 1, no. 12 (2014): 460-465.

8. Iman Satyarno, DinaHeldita, "Full height rectangular opening castellated steel beam partially encased in reinforced mortar", Procedia Engineering 171 (2017) 176-184

9. Listiyono Budi, Sukamta, Windu Partono, "Optimization analysis of size and distance of hexagonal hole in castellated steel beams", Procedia Engineering171 (2017) $1092-1099$.

10. Cristina Campian, Zsolt Nagy, Maria Pop, "Behavior of Fully Encased Steel-Concrete Composite Columns Subjected to Monotonic and Cyclic Loading", Procedia Engineering 117 (2015) 439 - 451. 